\title{
HEV prevalence and potential risk factors in a large multi-ethnic youth cohort in China
}

\author{
Huixia Li ${ }^{1 \dagger}$, Yinxia Zhang ${ }^{1 \dagger}$, Zhongren Ma ${ }^{1 \dagger}$, Zewen Liu', Aqsa Ikram', Lijiang Liu', Guoqin Zhao', Qiuwei Pan ' (D) \\ and Zulqarnain Baloch ${ }^{2^{*}}$ (D)
}

\begin{abstract}
Background: This cohort study was designed to investigate the prevalence of and potential risk factors of HEV infection in a large multi-ethnic youth cohort in China.

Methods: Blood samples were collected from participants $(n=6269)$ and serum was isolated. All serum samples were tested for anti-HEV IgG, anti-HEV IgM antibodies using commercial enzyme immunoassay kits (Wantai Biological Pharmacy Enterprise, Beijing, China).

Results: The overall rate of anti-HEV IgG and anti-HEV IgM prevalence was $4.78 \%$ and $0.14 \%, 0.03 \%$ were positive for both anti-HEV IgG and anti-HEV IgM antibodies. Anti-HEV IgG positivity is significantly higher in females (5.27\%) compared to males (4.14\%) ( $P=0.028)$. Anti-HEV IgG prevalence is significantly $(P=0.0001)$ higher in Dong (17.57\%), Miao (12.23\%), Yi (11.04\%), Gelao (9.76\%), and Bai (10.00\%) compared to other ethnic groups. It is significantly higher in Guizhou (11.4\%), Sichuan (10.1\%), Yunnan (9.3\%), and Guangxi (6.9\%) than that other province. We found that ethnicity and provincial background are significantly associated with HEV infection in this cohort.

Conclusion: This study provides comprehensive information on HEV prevalence in multi-ethnic populations in China. However, our study only focused on a youth population from different provinces of China. Future studies are recommended to investigate HEV prevalence in other age groups of the ethnic populations.
\end{abstract}

Keywords: Hepatitis E virus, Immunoglobulin M, Immunoglobulin G, Ethnic, China

\section{Background}

Hepatitis E, caused by the Hepatitis E virus (HEV) has emerged as an important health concern in both developed and developing countries [1]. In general, HEV infection is asymptomatic and self-limiting [2,3], but it can also cause severe diseases in specific populations, including pregnant women, immunocompromised patients, and patients with underlying liver diseases [4-6]. Globally, it is responsible for approximately 20 million new

\footnotetext{
*Correspondence: znbalooch@yahoo.com

${ }^{\dagger}$ Huixia Li, Yinxia Zhang, and Zhongren Ma have contributed equally and should be consider as first authors

${ }^{2}$ Faculty of Life Science and Technology, Kunming University of Science and Technology, Kunming 650500, Yunnan, China

Full list of author information is available at the end of the article
}

cases, over 3 million acute hepatitis cases, and 70,000 fatalities annually $[7,8]$. The HEV outbreaks were mainly common in developing countries compared to developed countries and its prevalence significantly varies based on ethnicity, socioeconomic conditions, food habits, water quality, sanitation and, geographic origin $[9,10]$.

The People's Republic of China is the leading populated country in the world, is comprised of 56 different ethnic groups with different dietary habits and living lifestyle. Therefore, different Chinese populations are prone to many food-borne infectious diseases, such as HEV infection. According to recent studies, the overall sero-prevalence of anti-HEV immunoglobulin G (IgG) among the general Chinese people's ranges from $11-72 \%[7,9,11]$, and that of IgM is $1.8 \%$ [9]. However, HEV prevalence among different ethnic populations at the national level original author(s) and the source, provide a link to the Creative Commons licence, and indicate if changes were made. The images or other third party material in this article are included in the article's Creative Commons licence, unless indicated otherwise in a credit line to the material. If material is not included in the article's Creative Commons licence and your intended use is not permitted by statutory regulation or exceeds the permitted use, you will need to obtain permission directly from the copyright holder. To view a copy of this licence, visit http://creativecommons.org/licenses/by/4.0/. The Creative Commons Public Domain Dedication waiver (http://creativeco mmons.org/publicdomain/zero/1.0/) applies to the data made available in this article, unless otherwise stated in a credit line to the data. 
has not been comprehensively studied. The majority of the ethnic populations are living in less developed areas in isolated communities with relatively poor sanitation, unhygienic food practices, socioeconomic condition, and lack of health facilities for prevention, diagnosis, and treatment of infectious diseases. Therefore, we designed this cohort study to investigate the sero-prevalence of IgG and IgM in large multi-ethnic Chinese youth and to understand potential risk factors.

\section{Methods}

\section{Study design}

We conducted this large multi-ethnic youth cohort study among the freshly enrolled students of Northwest Minzu University, a university dedicating to high education for ethnic populations in China. $5 \mathrm{ml}$ of blood was taken in sterile syringes from 6269 students and was immediately transported to the laboratory for further processing. In addition to sample collection, we used structured questionnaire forms to document participants' demographic characteristics such as age, sex, ethnicity, area, political status, major subject, college, City, province. The serum samples were stored at $-80{ }^{\circ} \mathrm{C}$, until further testing. In this study, all participants were above $16>$ year's age and never get $\mathrm{HEV}$ vaccination before.

\section{Serological tests}

Serum samples were tested for the presence of anti-HEV IgG and IgM antibodies using commercial-available enzyme immunoassay kits (Wantai Biological Pharmacy Enterprise, Beijing, China) according to the manufacturer's instructions. Samples were tested in duplicate with cutoff values for IgG and IgM assays set at 0.22 and 0.357 , respectively, which were determined based on the mean optical density 450 values from the negative controls (6 standard deviations). Samples with OD greater than or equal to the cutoff value were considered as positive.

\section{Statistical analysis}

The data was analyzed using SPSS version 20.0 (Chicago, IL, USA). Proportions were estimated with the $95 \%$ confidence interval $(\mathrm{CI}) \cdot X^{2}$ test or Fisher's exact test and Mantel-extension test for trend were performed to evaluate the difference in the prevalence of viral markers among sex, age, residential, and occupational groups. Univariate analysis using the $\chi^{2}$ test or Fisher's exact test and multivariate logistic regression analysis was performed to identify potential risk factors for HEV infection by calculating odds ratios (ORs) and 95\% CI. For all analyses, $P$-value $<0.05$ was considered statistically significant.

\section{Results}

\section{Demographic characteristics of the participants}

The demographic characteristics of all participants are shown in Table 1. In total, there were 6269 students, comprising of 3589 female and 2680 male. Age distribution was from $16>$ to 31 years (mean, $18.7 \pm 1.25$; median, 19 years). Among 6269 students, 1502 belonged to rural and 4678 to urban areas. A total of $36.56 \%$ of students were $\mathrm{Han}, 13.49 \%$ were Hui, $8.85 \%$ were Tibetan, $5.89 \%$ were Zhuang, $5.63 \%$ were Tujia, $4.47 \%$ were Uighur, $4.43 \%$ were Miao, $3.91 \%$ were Mongol, and the remaining belonged to others ethnicities (Table 1). In this study,

\section{Table 1 Demographic characteristics of participants}

\begin{tabular}{|c|c|c|}
\hline Ethnic & Total & Percentage \\
\hline \multicolumn{3}{|l|}{ Sex } \\
\hline Female & 3589 & 57.25 \\
\hline Male & 2680 & 42.75 \\
\hline \multicolumn{3}{|l|}{ Ethnic } \\
\hline Bai & 60 & 0.96 \\
\hline Bouyei & 74 & 1.18 \\
\hline Dong & 74 & 1.18 \\
\hline Dongxiang & 124 & 1.98 \\
\hline Gelao & 41 & 0.65 \\
\hline Han & 2292 & 36.56 \\
\hline Hui & 846 & 13.49 \\
\hline Kazakh & 40 & 0.64 \\
\hline $\mathrm{Li}$ & 69 & 1.10 \\
\hline Man & 118 & 1.88 \\
\hline Miao & 278 & 4.43 \\
\hline Mongol & 245 & 3.91 \\
\hline Monguor & 54 & 0.86 \\
\hline She & 26 & 0.40 \\
\hline Tibetan & 555 & 8.85 \\
\hline Tujia & 353 & 5.63 \\
\hline Uighur & 280 & 4.47 \\
\hline Yao & 56 & 0.89 \\
\hline Yi & 154 & 2.46 \\
\hline Zhuang & 369 & 5.89 \\
\hline Others* & 161 & 2.98 \\
\hline \multicolumn{3}{|l|}{ Age } \\
\hline$\leq 18$ years & 3069 & 48.96 \\
\hline $19 \& 20$ years & 2859 & 45.61 \\
\hline$\geq 21$ years & 341 & 5.44 \\
\hline \multicolumn{3}{|l|}{ Area } \\
\hline Rural & 1502 & 23.96 \\
\hline Urban & 4678 & 74.62 \\
\hline
\end{tabular}

*Other ethnics (Dai: 5, Daur:4, Derung:1, Hani:7, Hezhen:1, AcHang: 1, Blang: 2, Bonan: 3, Evenki:1, Gin: 2, Lahu: 1, Kirgiz/Kirghiz: 8, Korean:7, Lisu:10, Maonan: 2, Mulam: 10, Nakhi/Naxi: 12, Nu:1, Pumi: 3, Qiang: 3, Russ:1, Salar: 16, Sui: 13, unknown, 31, Uzbek:1, Va: 2, Xibe: 6, Yugur: 7) 
$14.15 \%$ of students belong to Gansu province followed by Guizhou (8.23\%), Guangxi (6.91\%), Xinjiang (6.81\%), Qinghai (6.52\%), Yunnan (6.36\%), Ningxia (5.44\%), Inner Mongolia (4.64\%), Hunan (4.47\%), Sichuan (4.10\%), Tibet (3.68\%), Chongqing (3.56\%), and the remaining were from others provinces (Additional file 1: Appendix Table 1).

\section{HEV sero-prevalence}

The overall sero-prevalence of anti-HEV IgG and IgM antibodies positive was $4.96 \%$ (311/6269). Among them, 300 participants $(4.79 \%)$ were anti-HEV IgG antibody positive IgM antibody negative, indicating past HEV infection. 11 participants $(0.18 \%)$ were positive with anti-HEV IgM, among them 2 participants $(0.03 \%)$ were positive for both anti-HEV IgG and IgM and 9 were negative for anti-HEV IgG, indicating recent/ongoing infection (Fig. 1). The results of serologic testing are shown in Table 2. Overall anti-HEV IgG (Past infection) prevalence was 4.79\% (300/6269; [95\% CI: 4.27-5.34]) and anti-HEV IgM (Recent or ongoing infection) prevalence was $0.18 \%$ [95\%CI: 0.09-0.31]. We next performed analysis on the characteristics of Anti-HEV IgG positivity (past infection) because IgM or both IgG and IgM positive samples are very limited. Anti-HEV IgG positivity was significantly higher in female participants $(5.27 \%)$ compared to male participants $(4.14 \%)(P=0.028)$. Similarly, anti-HEV IgG prevalence was significantly $(P=0.0001)$ higher in Dong (17.57\%), Miao (12.23\%), Yi (11.04\%), Bai (10.00), and Gelao (9.76\%) than that of other ethnic groups (Table 2).

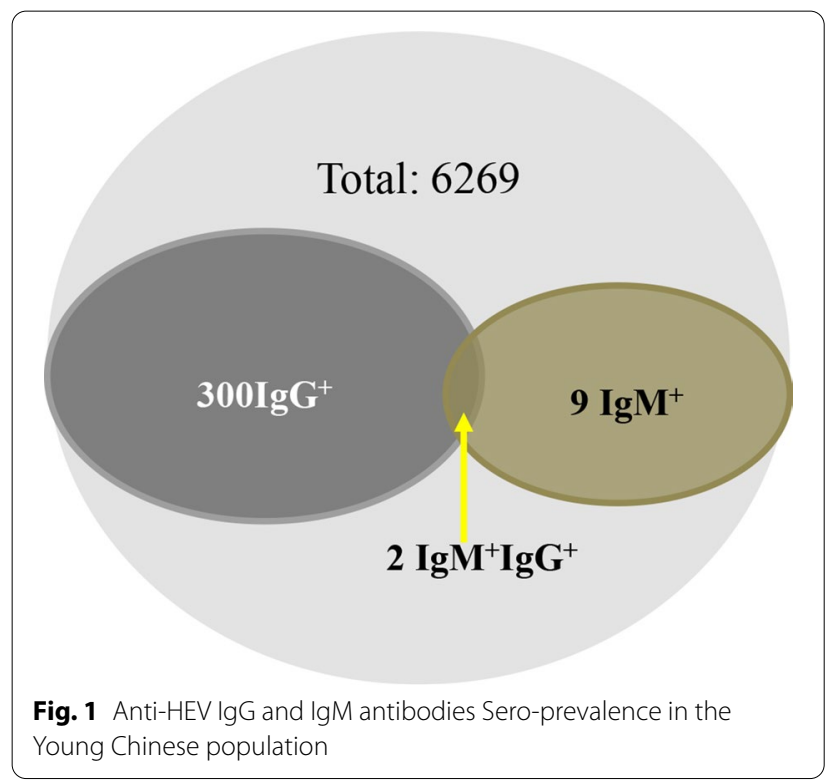

Anti-HEV IgG prevalence was significantly different among participants from different provinces $(P<0.0001)$ (Fig. 2). The overall anti-HEV IgG rate was significantly higher in Guizhou (11.4\%), Sichuan (10.1\%), Yunnan (9.3\%), and Guangxi (6.9\%) than that of other provinces (Fig. 2). 11 IgM positive samples were tested for viral RNA by qRT-PCR, but HEV RNA was undetectable.

\section{Potential risk factors for HEV infection}

To investigate the potential risk factors, only the samples positive for anti-HEV IgG were analyzed, which indicates past infection. Samples positive for IgM or both IgG and IgM, which indicates recent/ongoing infection, were not included because of the limited number. Univariate analysis revealed that sex, ethnic, and provincial backgrounds were significantly associated with a high rate of anti-HEV IgG antibody positivity. Interestingly, the multivariate analysis also indicated that ethnic and provincial background remained independent risk factors for the high rate of anti-HEV IgG positivity. The odds ratios and P-values of potential risk factors for antiHEV IgG in the multivariate logistic regression model are shown in Table 3. In multivariate analysis, anti-HEV IgG positivity in females was higher compared to males but the difference was not significant $(P=0.058)$. Additionally, we found that there was a strong statistical association between geographic location and HEV prevalence (Table 3). Interestingly, in multivariate logistic ethnicity was also significantly $(P=0.017)$ associated with antiHEV IgG positivity. The rate of anti-HEV IgG positivity was much higher in Dong, Miao, Yi, Gelao, Bai, and Yao compared to other ethnic groups (Table 3 ).

\section{Discussion}

HEV prevalence in general populations varies extensively across the world [12]. Previous studies on HEV sero-prevalence in China indicate varying results based on ethnicity [10] and geographical location [11, 13]. It has been documented that Hani population has the highest prevalence $(82.3 \%)$ followed by Naxi $(71.9 \%)$, Bulang (65.1\%),Wa (60.0\%) [10], Han (22.28\%), Mongolian (10.37\%), Tibetan (17.99\%), Uighur (46.61\%), Zhuang (72.02\%) and Hui (21.15\%) [11]. Different from these segmented previous studies, we now comprehensively investigated HEV prevalence in a large Chinese cohort comprising of 47 ethnicities from 31 provinces. Among 6269 tested samples, the sero-prevalence of anti-HEV IgG was $4.96 \%$ and anti-HEV IgM was $0.18 \%$ (Fig. 1). In China, previous studies reported anti-HEV IgG seroprevalence ranging from 10.8 to $66.58 \%$ in the general population $[9,10,13]$, which is considerably higher as compared to our study. Similarly, anti-HEV IgM prevalence in this study was $0.14 \%$, which is again lower as 
Table 2 HEV prevalence among various groups

\begin{tabular}{|c|c|c|c|c|c|}
\hline Ethnic & Total & $\begin{array}{l}\text { Anti-HEV IgG positive (rate } \\
\% \text { ) }\end{array}$ & $P$ value & $\begin{array}{l}\text { Anti-HEV IgM positive (rate } \\
\%)\end{array}$ & $P$-value \\
\hline Overall & 6269 & $300(4.8)$ & & $11(0.18)$ & \\
\hline Sex & & & $0.028^{*}$ & & 0.37 \\
\hline Female & 3589 & $189(5.3)$ & & $8(0.20)$ & \\
\hline Male & 2680 & $111(4.1)$ & & $3(0.11)$ & \\
\hline Ethnic & & & $0.0001 *$ & & \\
\hline Bai & 60 & $6(10.00)$ & & 0 & \\
\hline Bouyei & 74 & $6(8.1)$ & & 0 & \\
\hline Dong & 74 & $13(17.6)$ & & 0 & \\
\hline Dongxiang & 124 & $2(1.6)$ & & & \\
\hline Gelao & 41 & $4(9.8)$ & & 0 & \\
\hline Han & 2292 & $92(4.0)$ & & $3(0.13)$ & \\
\hline Hui & 846 & $16(1.9)$ & & $2(0.24)$ & \\
\hline Kazakh & 40 & $0(0.00)$ & & 0 & \\
\hline $\mathrm{Li}$ & 69 & $3(4.3)$ & & $1(1.45)$ & \\
\hline Man & 118 & $2(1.7)$ & & 0 & \\
\hline Miao & 278 & $34(12.2)$ & & $2(0.72)$ & \\
\hline Mongol & 245 & $4(1.6)$ & & 0 & \\
\hline Monguor & 54 & $4(7.4)$ & & 0 & \\
\hline She & 26 & $1(3.8)$ & & 0 & \\
\hline Others & 161 & $13(8.1)$ & & 0 & \\
\hline Tibetan & 555 & $31(5.6)$ & & 0 & \\
\hline Tujia & 353 & $15(4.2)$ & & $1(0.28)$ & \\
\hline Uighur & 280 & $9(3.2)$ & & 0 & \\
\hline Yao & 56 & $5(8.9)$ & & $1(0.35)$ & \\
\hline Yi & 154 & $17(11.0)$ & & $1(0.65)$ & \\
\hline Zhuang & 369 & $23(6.2)$ & & 0 & \\
\hline Age & & & 0.645 & & 0.29 \\
\hline$\leq 18$ years & 3069 & $145(4.7)$ & & $4(0.13)$ & \\
\hline 19 and 20 years & 2859 & $135(4.7)$ & & $5(0.17)$ & \\
\hline$\geq 21$ years & 341 & $20(5.9)$ & & $2(0.59)$ & \\
\hline Area & & & 0.215 & & 0.25 \\
\hline Rural & 1502 & $82(5.5)$ & & $4(0.27)$ & \\
\hline Urban & 4678 & $216(4.6)$ & & $7(0.15)$ & \\
\hline
\end{tabular}

Bold values indicated statistically significant

Data were presented as $\mathrm{n}$ (\%)

*The results from the Chi Square Test

compared to previous studies, $0.84-1.8 \%$ among the general population $[9,10]$ and $0.5-5 \%$ in blood donors in China [14]. The potential reasons may be attributed to factors such as participants from diverse geographies, different populations, age groups $[13,15,16]$, and the use of diagnostic assays with different sensitivities [17].

In this study, we found a high HEV prevalence in Dong (17.6\%), Miao (12.23\%), Yi (11.04\%), Bai $(10.2 \%)$, and Gelao (9.8\%) than that of other ethnic groups (Table 2). The mmajority of Dong, Miao, Yi, Gelao, and Bai ethnic groups are populated in Sichuan, Yunnan, Guangxi, and
Guizhou province of China. These provinces are mostly overpopulated and less developed $[13,18]$. The anti-HEV IgG rate among the 28 provinces investigated in this study ranges from $0 \%$ to $11.4 \%$ (Fig. 2). The overall rate was higher in Guizhou (11.4\%), Sichuan (10.1\%), Yunnan (9.3\%), and Guangxi (6.9\%), consistent with our findings of high prevalence in ethnic groups mainly from these provinces [18].

When we analyzed different potential risk factors data acquired from the self-reported questionnaires using univariate and multivariate logistic regression analysis. 


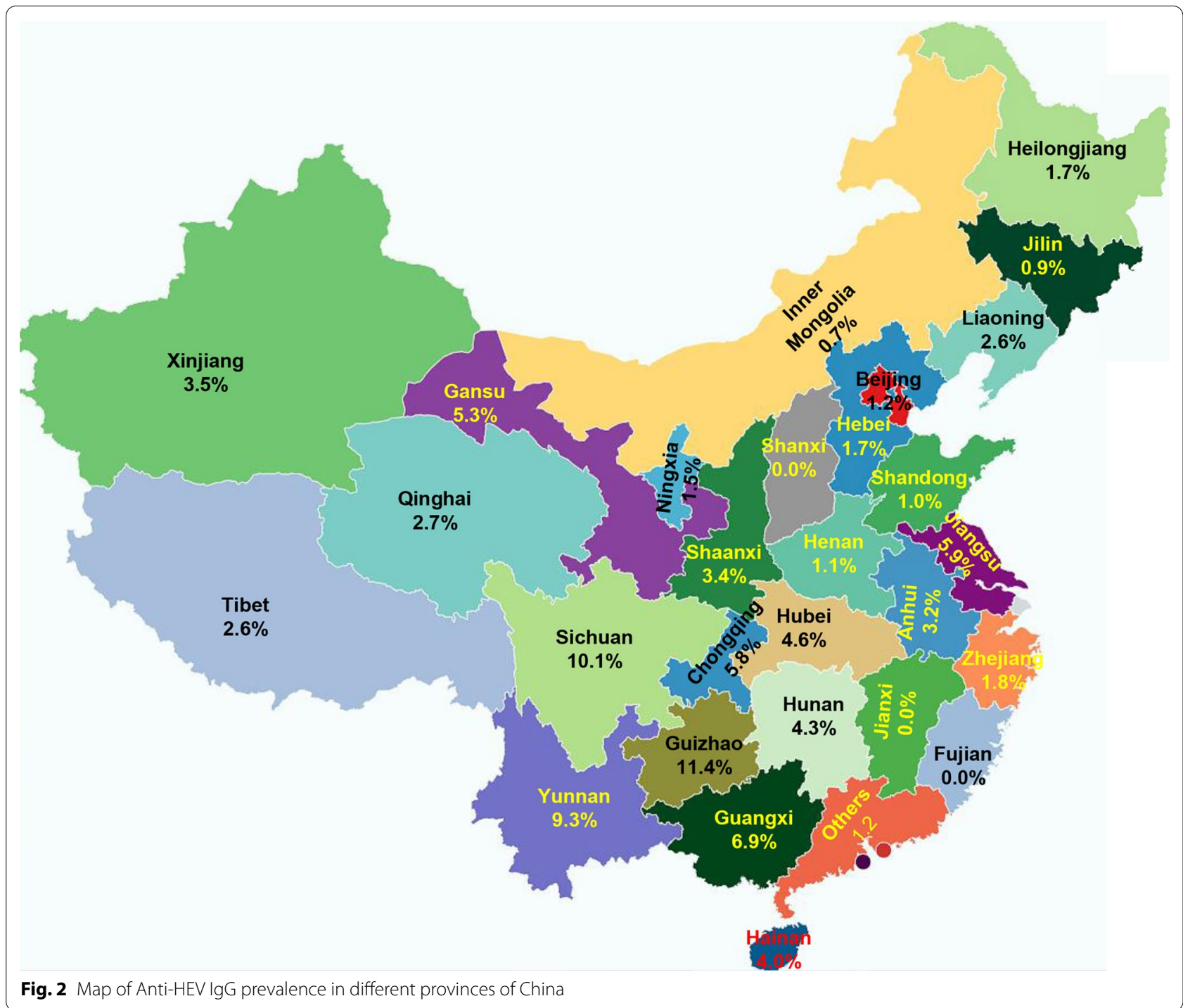

Our analysis revealed that ethnicity and provincial background are significantly associated with anti-HEV IgG (Table 3). We found that anti-HEV IgG sero-prevalence was higher in females as compared to males but the difference was not significant. Similar results have been reported [19-21] but others observed the opposite [22, 23]. However, there is to date no evidence-based explanation on the sex disparity to HEV susceptibility, requiring further investigation. It is well accepted that HEV infection occurs at all ages, and thus the anti-HEV IgG rate increases with the growing of age. In this study, anti-HEV IgG prevalence ranges from $4.72-5.87 \%$ without significant differences among different age groups. This can be explained that we enrolled in a relatively homogeneous youth group. $94.6 \%$ of participants are less than 20 years old in this study, and therefore, young age might be the main contributor to the overall low HEV prevalence.
This study has limitations that must be considered when interpreting our findings. First, HEV RNA was not detected and therefore we could not confirm the circulating genotype in our population. Secondly, the information of several known risk factors, including dietary habits, living standards, travel history, family history, and profession were not available in this study. Finally, we were only able to recruit a youth cohort for practical reasons. Thus, the epidemiology of HEV infection in other age groups of Chinese ethnic populations remains to be investigated.

\section{Conclusion}

This study provides comprehensive epidemiological information on HEV prevalence in the multi-ethnic populations residing in different provinces of China. 
Table 3 Multivariate logistic regression analysis

\begin{tabular}{|c|c|c|c|c|}
\hline Variables & Total & $\begin{array}{l}\text { Positive for anti- } \\
\text { HEV IgG (rate \%) }\end{array}$ & $P$-value & OR $(95 \% \mathrm{Cl})$ \\
\hline Sex & & & $0.058^{*}$ & \\
\hline Female & 3589 & $189(5.3)$ & & 1 \\
\hline Male & 2680 & $111(4.1)$ & & $0.78(0.62-1.00)$ \\
\hline Ethnic & & & $0.017^{*}$ & \\
\hline Overall & 6269 & $300(4.8)$ & & 1 \\
\hline Bai & 60 & $6(10.0)$ & & $1.67(0.65-4.29)$ \\
\hline Bouyei & 74 & $6(8.1)$ & & $1.33(0.52-3.38)$ \\
\hline Dong & 74 & $13(17.6)$ & & $3.21(1.54-6.67)$ \\
\hline Dongxiang & 124 & $2(1.6)$ & & $0.25(0.06-1.06)$ \\
\hline Gelao & 41 & $4(9.8)$ & & $1.63(0.53-4.96)$ \\
\hline Han & 2292 & $92(4.0)$ & & $0.63(0.39-1.01)$ \\
\hline Hui & 846 & $16(1.9)$ & & $0.29(0.15-0.56)$ \\
\hline Kazakh & 40 & $0(0.0)$ & & 0.0 \\
\hline $\mathrm{Li}$ & 69 & $3(4.3)$ & & $0.68(0.20-2.34)$ \\
\hline Man & 118 & $2(1.7)$ & & $0.26(0.06-1.12)$ \\
\hline Miao & 278 & $34(12.2)$ & & $2.1(1.20-3.65)$ \\
\hline Mongol & 245 & $4(1.6)$ & & $0.25(0.08-0.73)$ \\
\hline Monguor & 54 & $4(7.4)$ & & $1.20(0.40-3.62)$ \\
\hline Others & 161 & $13(8.1)$ & & $1.32(0.40-3.62)$ \\
\hline She & 26 & $1(3.85)$ & & $0.60(0.08-4.64)$ \\
\hline Tibetan & 555 & $31(5.6)$ & & $0.89(0.51-1.55)$ \\
\hline Tujia & 353 & $15(4.2)$ & & $0.67(0.34-1.30)$ \\
\hline Uighur & 280 & $9(3.2)$ & & $0.50(0.23-1.10)$ \\
\hline Yao & 56 & $5(8.9)$ & & $1.47(0.54-4.05)$ \\
\hline Yi & 154 & $17(11.0)$ & & $1.87(0.97-3.60)$ \\
\hline Zhuang & 369 & $23(6.2)$ & & $1.00(0.65-1.48)$ \\
\hline Province & & & $0.00^{*}$ & \\
\hline Overall & 6269 & $300(4.8)$ & & 1 \\
\hline Anhui & 62 & $2(3.2)$ & & $0.97(0.16-8.75)$ \\
\hline Chongqing & 223 & $13(5.8)$ & & $1.85(0.41-8.46)$ \\
\hline Fujian & 67 & $0(0.0)$ & & 0 \\
\hline Gansu & 887 & $47(5.3)$ & & $1.68(0.40-7.08)$ \\
\hline Guangxi & 433 & $29(6.9)$ & & $2.23(0.52-9.59)$ \\
\hline Guizhou & 516 & $59(11.4)$ & & $3.87(0.92-16.26)$ \\
\hline Hainan & 101 & $4(4.0)$ & & $1.24(0.22-6.96)$ \\
\hline Hebei & 118 & $2(1.7)$ & & $0.52(0.07-3.76)$ \\
\hline Heilongjiang & 119 & $2(1.7)$ & & $0.51(0.07-3.73)$ \\
\hline Henan & 176 & $2(1.1)$ & & $0.34(0.05-2.49)$ \\
\hline Hubei & 151 & $7(4.6)$ & & $1.47(0.30-7.27)$ \\
\hline Hunan & 280 & $12(4.3)$ & & $1.34(0.29-6.17)$ \\
\hline Inner Mongolia & 291 & $2(0.7)$ & & $0.21(0.03-1.50)$ \\
\hline Jiangsu & 51 & $3(5.9)$ & & $1.87(0.30-11.68)$ \\
\hline Jiangxi & 54 & $3(5.6)$ & & $1.76(0.28-10.98)$ \\
\hline Jilin & 112 & $1(0.9)$ & & $0.27(0.02-3.04)$ \\
\hline Liaoning & 152 & $4(2.6)$ & & $0.81(0.14-4.54)$ \\
\hline Ningxia & 341 & $5(1.5)$ & & $0.45(0.08-2.35)$ \\
\hline Qinghai & 409 & $11(2.7)$ & & $0.83(0.18-3.83)$ \\
\hline Shaanxi & 118 & $4(3.4)$ & & $1.05(0.19-5.91)$ \\
\hline Shandong & 104 & $1(1.0)$ & & $0.29(0.03-3.28)$ \\
\hline
\end{tabular}

Table 3 (continued)

\begin{tabular}{|c|c|c|c|}
\hline Variables & Total & $\begin{array}{l}\text { Positive for anti- } P \text {-value } \\
\text { HEV lgG (rate \%) }\end{array}$ & OR $(95 \% \mathrm{Cl})$ \\
\hline Shanxi & 51 & $0(0.0)$ & 0.00 \\
\hline Sichuan & 257 & $26(10.1)$ & $3.38(0.78-14.63)$ \\
\hline Others & 82 & $1(1.2)$ & $0.37(0.03-4.18)$ \\
\hline Tibet & 231 & $6(2.6)$ & $0.80(0.16-4.06)$ \\
\hline Xinjiang & 427 & $15(3.5)$ & $1.09(0.24-4.89)$ \\
\hline Yunnan & 399 & $37(9.3)$ & $3.06(0.72-13.06)$ \\
\hline Zhejiang & 57 & $1(1.8)$ & $0.54(0.05-6.07)$ \\
\hline
\end{tabular}

*The ORs and 95\% confidence intervals (Cls) use multivariate logistic regression analysis

\# Others provinces (Beijing: 4, Guangdong: 18, Shanghai: 6, Tianjin: 6 and unknown (not mentioned provincial background detail: 48 )

We report the positive rate of anti-HEV IgG antibodies of $4.79 \%$ and IgM antibodies of $0.14 \%$. HEV infection appears to be associated with sex, ethnic, and provincial background in our population.

\section{Supplementary information}

The online version contains supplementary material available at https://doi. org/10.1186/s12985-020-01470-3.

Additional file 1. Participants provincial background.

\section{Abbreviation}

HEV: Hepatitis E virus.

\section{Acknowledgements}

We sincerely thank all the participants who took part in this study.

Authors' contributions

All authors contributed to the concept of this study. PQ, MZ, and ZB designed the study. $L H, L Z, Y Z, A I, L L$ and $G H$ analyzed data and wrote the manuscript. $P Q, M Z$, and $Z B$ approved the final manuscript. All authors reviewed and approved the final draft. All authors read and approved the final manuscript.

\section{Funding}

The work was supported by the Ministry of Education of China for an Innovative Research Team in University grant (No. IRT_17R88; to Z.M.) and the Fundamental Research Funds for the Central Universities (No. 31920200072). Funders has no role in the design of the study and collection, analysis, and interpretation of data, writing and publishing the manuscript.

\section{Availability of data and materials}

The aggregate data supporting findings contained within this manuscript will be shared upon request submitted to the corresponding author. Identifying patient data will not be shared.

\section{Ethics approval and consent to participate}

The protocol used in this study was in accordance with the Declaration of Helsinki and was approved by the Ethics Committee at Northwest Minzu University Lanzhou, China. Written consent was individually obtained from the participants

\section{Consent for publication \\ $\mathrm{n} / \mathrm{a}$}

Competing interests

All authors declare they have no actual or potential competing interests. 


\section{Author details}

${ }^{1}$ Key Laboratory of Biotechnology and Bioengineering of State Ethnic Affairs Commission, Biomedical Research Center, Northwest Minzu University, Lanzhou, China. ${ }^{2}$ Faculty of Life Science and Technology, Kunming University of Science and Technology, Kunming 650500, Yunnan, China.

Received: 16 July 2020 Accepted: 9 December 2020

Published online: 06 January 2021

\section{References}

1. Khuroo MS, Khuroo MS, Khuroo NS. Transmission of Hepatitis E virus in developing countries. Viruses-Basel 2016, 8(9).

2. Lhomme S, Marion O, Abravanel F, Chapuy-Regaud S, Kamar N, Izopet J. Hepatitis E pathogenesis. Viruses-Basel 2016, 8(8)

3. Abrayanel F, Pique J, Couturier E, Nicot F, Dimeglio C, Lhomme S, Chiabrando J, Saune K, Peron JM, Kamar N, et al. Acute hepatitis $E$ in French patients and neurological manifestations. J Infection. 2018;77(3):220-6.

4. Zhou XY, de Man RA, de Knegt RJ, Metselaar HJ, Peppelenbosch MP, Pan QW. Epidemiology and management of chronic hepatitis E infection in solid organ transplantation: a comprehensive literature review. Rev Med Virol. 2013:23(5):295-304.

5. Mushahwar IK. Hepatitis E virus: Molecular virology, clinical features, diagnosis, transmission, epidemiology, and prevention. J Med Virol. 2008:80(4):646-58.

6. Zhou SY, Ren L, Xia XS, Miao ZJ, Huang F, Li YL, Zhu M, Xie ZR, Xu Y, Qian $Y$, et al. Hepatitis $E$ virus infection in HIV-infected patients: a large cohort study in Yunnan province China. J Med Virol. 2018;90(6):1121-7.

7. Hakim MS, Wang WS, Bramer WM, Geng JW, Huang F, de Man RA, Peppelenbosch MP, Pan QW. The global burden of hepatitis E outbreaks: a systematic review. Liver Int. 2017;37(1):19-31.

8. Rein DB, Stevens GA, Theaker J, Wittenborn JS, Wiersma ST. The global burden of hepatitis E virus genotypes 1 and 2 in 2005. Hepatology. 2012;55(4):988-97.

9. Yue N, Wang Q, Zheng MY, Wang DL, Duan CX, Yu XG, Zhang XF, Bao CJ, Jin $\mathrm{H}$. Prevalence of hepatitis $E$ virus infection among people and swine in mainland China: a systematic review and meta-analysis. Zoonoses Public Hlth. 2019;66(3):265-75.

10. Feng $Y$, Feng $Y M$, Wang SM, Xu F, Zhang XH, Zhang $C Y$, Jia $Y Y$, Yang WR, Xia $X S$, Yin JZ. High seroprevalence of hepatitis $E$ virus in the ethnic minority populations in Yunnan, China. PloS one 2018, 13(5).

11. Jia ZY, Yi Y, Liu JH, Cao JY, Zhang Y, Tian RG, Yu T, Wang H, Wang XY, Su QD et al. Epidemiology of Hepatitis E Virus in China: results from the Third National Viral Hepatitis Prevalence Survey, 2005-2006. PloS one 2014, 9(10).
12. Dalton HR, Bendall R, ljaz S, Banks M. Hepatitis E: an emerging infection in developed countries. Lancet Infectious Dis. 2008;8(11):698-709.

13. Dong C, Dai X, Liang JH, Dong M, Meng JH. Seroprevalence of Hepatitis E Virus varies considerably among Chinese Provinces. Hepat Mon. 2012;12(6):386-90.

14. Wang MY, Fu P, Yin YH, He M, Liu Y. Acute, recent and past HEV infection among voluntary blood donors in China: a systematic review and metaanalysis. Plos One 2016, 11 (9).

15. Lagler H, Poeppl W, Winkler H, Herkner H, Faas A, Mooseder G, Burgmann H. Hepatitis E virus seroprevalence in Austrian Adults: a nationwide crosssectional study among civilians and military professionals. PloS one 2014, 9(2).

16. Verhoef L, Koopmans M, Duizer E, Bakker J, Reimerink J, van Pelt W. Seroprevalence of hepatitis $\mathrm{E}$ antibodies and risk profile of HEV seropositivity in The Netherlands, 2006-2007. Epidemiol Infect. 2012;140(10):1838-47.

17. Passos-Castilho AM, Reinaldo MR, de Sena A, Granato CFH. High prevalence of hepatitis E virus antibodies in Sao Paulo, Southeastern Brazil: analysis of a group of blood donors representative of the general population. Braz J Infect Dis. 2017;21(5):535-9.

18. Lu J, Zhou YD, Lin XJ, Jiang YZ, Tian RG, Zhang YH, Wu J, Zhang FW, Zhang $Y$, Wang $Y$ et al. General epidemiological parameters of viral hepatitis A, B, $C$, and $E$ in six regions of China: a cross-sectional study in 2007. PloS one 2009, 4(12).

19. Yamada H, Takahashi K, Lim O, Svay S, Chuon C, Hok S, Do SH, Fujimoto M, Akita T, Goto N et al. Hepatitis E Virus in Cambodia: prevalence among the general population and complete genome sequence of genotype 4. Plos one $2015,10(8)$

20. Takahashi M, Tamura K, Hoshino Y, Nagashima S, Yazaki Y, Mizuo H, Iwamoto S, Okayama M, Nakamura Y, Kajii E, et al. A Nationwide Survey of Hepatitis E Virus Infection in the General Population of Japan. J Med Virol. 2010;82(2):271-81

21. Mansuy JM, Gallian P, Dimeglio C, Saune K, Arnaud C, Pelletier B, Morel P, Legrand D, Tiberghien P, Izopet J. A Nationwide Survey of Hepatitis E Viral Infection in French Blood Donors. Hepatology. 2016;63(4):1145-54.

22. van Gageldonk-Lafeber AB, van der Hoek W, Borlee F, Heederik DJJ, Mooi SH, Maassen CBM, Yzermans CJ, Rockx B, Smit LAM, Reimerink $J \mathrm{HJ}$. Hepatitis E virus seroprevalence among the general population in a livestock-dense area in the Netherlands: a cross-sectional populationbased serological survey. BMC Infect Dis. 2017, 17.

23. El-Tras WF, Tayel AA, El-Kady NN. Seroprevalence of Hepatitis E Virus in humans and geographically matched food animals in Egypt. Zoonoses Public Hlth. 2013;60(3):244-51.

\section{Publisher's Note}

Springer Nature remains neutral with regard to jurisdictional claims in published maps and institutional affiliations.
Ready to submit your research? Choose BMC and benefit from:

- fast, convenient online submission

- thorough peer review by experienced researchers in your field

- rapid publication on acceptance

- support for research data, including large and complex data types

- gold Open Access which fosters wider collaboration and increased citations

- maximum visibility for your research: over 100M website views per year

At BMC, research is always in progress.

Learn more biomedcentral.com/submissions 